\title{
Farmer's Perception and Determinants of Insecurity Management of the Farm Enterprise in Bauchi State, Nigeria
}

\author{
Enimu Solomon $\mathrm{PhD}^{1 *}$ and Isa Umar Kyari $\mathrm{PhD}^{2}$ \\ 1Department of Agricultural Economics, University of Calabar, Calabar, Cross River State, Nigeria \\ 2Department of Crop Science, College of Agriculture, Jalingo, Taraba State, Nigeria \\ *Corresponding Author \\ Dr. Enimu Solomon
}

\author{
Article History \\ Received: 14.08.2019 \\ Accepted: 27.08 .2019 \\ Published: 15.09 .2019
}

\begin{abstract}
This study on farmer's perception and determinants of insecurity management of the farm enterprise was carried out in Bauchi State, Nigeria. It among others identified farmers' perceived insecurities in the farm enterprise, adopted measures for mitigation of their effects and determined factors that influence farmer's management strategy towards insecurities. Three hundred and ten (310) farmers were selected using both the random sampling and snow balling sampling techniques for both crop farmers and the nomadic pastoralists where data was collected from them using well structured questionnaire complimented with personal interview methods. The data collected were analyzed using descriptive statistics such as table, frequency, percentages, chi-square and binary probit model. The results obtained from the analysis showed that herders/farmers clashes, drought, fire outbreak, diseases, inadequate technologies, ill health, policy inconsistency, pricing/hedge out, kidnapping, pests, cultural/social taboos, theft/roastling and soil erosion as insecurities experienced by the farmers. The most perceived insecurity was herders/farmers clashes and the least perceived was soil erosion. The socio-economic determinants of the farmers that significantly influenced their management strategies to farm enterprise insecurity include: education $(p<0.01)$, farming experience $(p<0.01)$, farm size $(p<0.05)$, household size $(p<0.05)$, distance $(p<.0 .01)$, household income $(p<0.10)$ and perception level $(p<0.05)$. Based on these findings, the study recommended that farmers should be encourage to take up formal insurance policy against losses, ranching should be encouraged with the formation of local vigilante, and socio-economic capacity building of farmers in effective management of security challenges towards sustainable agricultural development and food security.
\end{abstract}

Keywords: Perception, determinants, insecurity, management, enterprise.

\section{INTRODUCTION}

Agriculture is the mainstay of the rural economy and by extension, the dominant sector in Nigeria economy. The sector provides employment for about $75 \%$ of the country's population and contributed about $41 \%$ of the nation's Gross Domestic product (GDP) in the year 2018 [1]. The agricultural sector is not only the most important non-oil economic activity in Nigeria; it is also the single largest employer of labour forces [2]. This sector comprises crops, livestock, fishing and forestry, all of which play important roles in the economy of the nation.

Agricultural sector existence is being challenged by insecurity of several origins; nature (i.e climatic and man-made), economic and trade (pricing of national and international hedge-out), Technology (paucity and inapplicability and difference of scientific and research amalgam and in aggregation), political and administration (governmental, bureaucracy, and policy summersault and inconsistency), input and knowledge based farmers types, cultural and social behaviours and attitudinize among others [3]. The continuum of security challenges vis-à-vis food security and agricultural development is mind bugging and seeks a decorance from human beings.

Agricultural production depends much on weather, climate and soil condition. Most times natural disasters occasioned adverse climate and weather elements bring about droughts, extreme temperature and rainfall, flood, erosion, leaching that manifest in animal death, famine, crop failure, loss of properties, food insecurity, mass migration and negative growth of the economy [4]. Natural disasters to a farmer are hazards that demand prompt attention. Cherry [5] was of the opinion that perception is a sensory

Copyright @ 2019: This is an open-access article distributed under the terms of the Creative Commons Attribution license which permits unrestricted use, distribution, and reproduction in any medium for non commercial use (NonCommercial, or CC-BY-NC) provided the original author and source are credited. 
experience of the world around the perceiver that allows him/her recognize both environmental stimuli and take actions in response to them.

The stability of a nation is a guarantee to food production, any nation that is unstable cannot enjoy full agricultural activities. The citizenry thinks of safety and ability to move and do their domestic chores. Activities involved in production demands the total wellness of a person (physical, mental, social etc); it cannot be done half hazardly [3]. It is no doubt that the nation Nigeria is blessed but the present security challenges causes the movement of people to seek safety in another environment other than where they are used to and carryout production activities and it is a great concern as farmlands are abandoned and agricultural project forfeited. A single disaster can stunt agricultural growth for many years due to cost production, damaged infrastructure and diversions of scarce resources for recovery needs [6]. The likelihood that insecurity will result in a decline in well being of farming in an area (vulnerability) can be managed considerably by accurate and timely predication and prompt taking of counter measures to reduce their impact on agriculture [7].

Farming is financially risky as on daily basis farmers are confronted with changing security challenges [4]. Agricultural risks have over years been associated with negative outcomes of imperfectly predictable biological, climatic and price variables under the control of agricultural producers [8]. Many adjustments and processes to insecurity in agriculture have centered on land use planning, construction of structures to control natural processes, formal insurance policies, evaluation, disaster preparedness and bearing losses, which option a farmer, chooses depends on a number of factors that must include hazard perception [9]. There has not been a comprehensive empirical approach to the study of insecurity management of the farm enterprise. It is therefore pertinent to statistically examine the various factors that facilitate the farmer's perception and choice of insecurity management.

\section{ObJeCtives OF THE Study}

The main objective of this study is to examine farmer's perception and determinants of insecurity management in the farm enterprise in Bauchi state, Nigeria. The specific objectives are to:

- Identify farmer's experienced insecurities and classify level of perception.

- Identify measures used in mitigating impacts of the insecurities.

- Determine factors that influence farmer's management strategies towards insecurities in the study area.

\section{The Study's Hypothesis}

The study was guided by the following null hypothesis. No significant relationship exists between the selected variables and farmer's management of insecurities in the farm enterprise.

\section{MethOdS}

\section{Study Area, Sampling and Data Collection}

The study was conducted in Bauchi State, Nigeria. The state is located in the north eastern region of Nigeria and occupies a total land area of $49,119 \mathrm{~km}^{2}$ and it lies between the coordinates of latitude $10^{0} 30^{1} \mathrm{~N} 10^{0} 00^{1} \mathrm{E}$ and $10.5 ; 1010.5 ; 10$ [10]. According to Census 2006, it has population of 4,676,465 people. The state is made up of three agricultural zones (Western, Central and Northern) based on Bauchi State Agricultural Development Programme. The state is characterized by two distinct vegetative zones which include Northern Guinea Savannah and Sudan Savannah that experienced both wet and dry season with temperatures ranging between $15^{\circ} \mathrm{c}-29.7^{\circ} \mathrm{c}$ in January to $23^{\circ} \mathrm{c}-32.4^{\circ} \mathrm{c}$ in June with an average relative humidity of 40.1 percent. It is also characterized with an average annual rainfall of $85.6 \mathrm{~mm}$ [11]. Agriculture is the main occupation of the people. The crops grown by farmers in the state include rice, millet, yam, vegetables, maize, and cassava. Within the state, the livestock kept include cattle, goat, sheep, poultry and fishery.

\section{Sampling Procedure and Data Collection/Analysis}

The sampling frame for this study was drawn from farmers and pastoralists. The random sampling technique was used for the selection of 205 farmers from the three agricultural zones using the list of registered farmers collected from the Bauchi State Agricultural Development Programme (BSADP), while a snow balling sampling techniques was used for the selection of 105 pastoralist who were sparsely distributed and nomadic in nature.

Primary data were gathered by means of a well-structured questionnaire complimented with oral interview on farmers and pastoralists' socio-economic characteristics, sources of insecurities, perception of insecurity and its impacts, while secondary data were sourced from relevant published and unpublished materials. Data collected were analyzed using both descriptive and inferential statistic such as mean, percentage, table, frequency, chi-square and binary probit regression model.

In classifying farmer's and pastoralists' level of perception of farm insecurities individual Likert type questions on a five-point scale was used. Perception category nominal scores were: strongly agree (5); agree (4); undecided (3); strongly disagree (2); disagree (1). The mean nominal score was $(1+2+3+4+5) 15=3.0$. Farmers with acceptance score of 3.0 and above were considered to have perceived and those with mean scores of below 3.0 were considered to have not perceived the insecurities. 


\section{The Empirical Model}

The probit multiple regression model was used to examine the factors that determined household choice of management strategies towards insecurities. The probability of decision making were thus subjected to a model of limited dependent variable as introduced by Tobin [12] and as applied by Amamiya [13] and corrected for bias in participation decision [14]. This probit model was stated as follows:

$$
\mathrm{Y}_{\mathrm{ij}}=\boldsymbol{x}_{\mathrm{j}}+\beta_{\mathrm{j}} \sum_{\mathrm{k}=1}^{\mathrm{s}} \mathrm{H}_{\mathrm{ijs}}+\Sigma_{\mathrm{ij}}
$$

Where the $\mathrm{H}_{\mathrm{ijs}}$ are vectors of explanatory variables of the jth farm household deciding to choose a management strategy to counter insecurities; $Y_{i j}$ is a vector of binary variables such that $Y_{i j}=1$ if the jth household uses management strategies on its farm enterprise(s), and 0 otherwise. Since $Y_{\mathrm{ij}}$ can only assume two different values from the decision, 1 or 0 , the expected probability was defined as follows:

$$
\begin{aligned}
& E\left(Y_{i j}\right)=E\left(\varkappa_{j}+\beta_{j} \quad \sum_{k=1}^{2} H_{i j s}+\Sigma_{i j}\right] \\
& =x_{j}+\beta_{j} \quad \sum_{k=1}^{s} H_{i j s}+E\left(H_{i j}\right)_{--}
\end{aligned}
$$

Equation (2) defines the proportion of farmers with characteristics $\left(\mathrm{H}_{\mathrm{ij}}\right)$ likely to take insecurity management strategies in their farm enterprise.

The empirical model was specified thus:

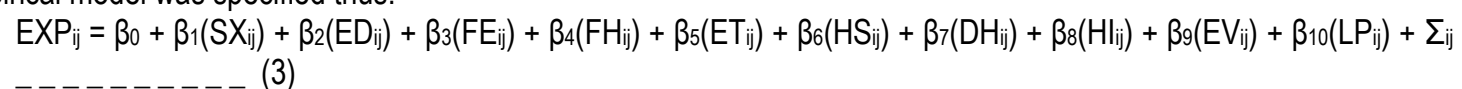

$\begin{array}{lll}\mathrm{EXP}_{\mathrm{ij}}= & \text { Dichotomous probability estimate with 1, if farmers were using } \\ \text { in their farm enterprises and } 0 \text { if otherwise. } \\ \beta_{0} \quad= & \text { Intercept } \\ \beta_{1} & = & \text { Coefficients of the independent variables } \\ \mathrm{SX}_{\mathrm{ij}} & = & \text { Sex of the household head (Dummy in 1 = male, } 0 \text { = female). } \\ \mathrm{ED}_{\mathrm{ij}} & = & \text { Years of Education (continuous in number). } \\ \mathrm{FE}_{\mathrm{ij}} & = & \text { Years of Farming Experience (continuous in number). } \\ \mathrm{FH}_{\mathrm{ij}} & = & \text { Farm/Herd Size (continuous in number). } \\ \mathrm{ET}_{\mathrm{ij}} & = & \text { Enterprise type (Dummy in 1 = crop, } 0=\text { livestock) } \\ \mathrm{HS}_{\mathrm{ij}} & = & \text { Household size (continuous in number of persons). } \\ \mathrm{DH}_{\mathrm{ij}} & = & \text { Distance to Home (continuous in number of km). } \\ \mathrm{Hl}_{\mathrm{lij}} & = & \text { Income of household head (continuous in amount of Naira). } \\ \mathrm{EV}_{\mathrm{ij}} & = & \text { Extension visits (continuous in number). } \\ \mathrm{LP}_{\mathrm{ij}} & = & \text { Level of perception (Dummy in 1 = Yes, } 0=\text { No). } \\ \Sigma \mathrm{ij} & = & \text { The stochastic error term. }\end{array}$

\section{RESULTS AND DISCUSSION}

\section{Socio-economic Characteristics of the Respondents}

The socio-economic characteristic of the respondents considered in this study include gender, educational level, years of farming experience, farm/herd size, household size, distance from home, age, household income, extension visit and major enterprise. Table-1 revealed that $85 \%$ of the respondents were male while $15 \%$ were female. This result is in agreement with the report of CIAS [15] where it was revealed that gender of labour measurement plays a major role in human activities and agriculture is not excluded from this fact because weight is attached to labour thereby making gender an important influence in the labour availability. Formal and informal knowledge, no doubt is necessary in managing enterprise challenges. The educational attainment was relatively high as cumulatively $73.2 \%$ of the respondent received formal education while $26.8 \%$ had no formal education. A reasonable experience in farming no doubt enhances a farmer's awareness of insecurities and compels him to device unique mitigation measure to reduce the negative impact. Table- 1 reveals that majority $45.8 \%$ of the respondents had above 10 years farming experience while $35.8 \%$ and $18.4 \%$ had farming experiences of $5-10 y e a r s$ and less than 5years respectively. 
Table-1: Socio-Economic Characteristics of Respondents

\begin{tabular}{|l|c|c|l|c|c|}
\hline Variables & $\mathbf{F}$ & $\%$ & Variables & $\mathbf{F}$ & $\%$ \\
\hline Sex of farmer & & & $11-30$ & 131 & 42.3 \\
\hline Male & 262 & 84.5 & $31-50$ & 57 & 18.4 \\
\hline Female & 48 & 15.5 & $>50$ & 39 & 12.6 \\
\hline Education level & & & Age of respondent & & \\
\hline No-formal education & 83 & 26.8 & $<20$ & 17 & 5.5 \\
\hline Primary education & 108 & 34.8 & $20-30$ & 61 & 19.7 \\
\hline Secondary education & 64 & 20.6 & $31-40$ & 92 & 29.7 \\
\hline Tertiary education & 12 & 3.9 & $41-50$ & 113 & 36.5 \\
\hline Farming Experience & 43 & 13.9 & $>50$ & 27 & 8.7 \\
\hline$<5$ & 57 & 18.4 & Household income & & \\
\hline $5-10$ & 111 & 35.8 & $<50,000$ & 59 & 19.0 \\
\hline$>10$ & 142 & 45.8 & $50,000-100,000$ & 187 & 60.3 \\
\hline Farm Size & & & $100,000-200,000$ & 36 & 11.6 \\
\hline$<1$ & 72 & 23.2 & $>200,000$ & 28 & 9.0 \\
\hline $1.0-2.0$ & 183 & 59.0 & Extension visit & & \\
\hline $2.0-3.0$ & 37 & 11.9 & $<5$ & 98 & 31.6 \\
\hline$>4.0$ & 18 & 5.8 & $5-10$ & 183 & 59.0 \\
\hline Household Size & & & $>10$ & 29 & 9.4 \\
\hline $1-5$ & 35 & 11.3 & Major Enterprise & & \\
\hline $6-11$ & 182 & 58.7 & Crop & 205 & 66.1 \\
\hline$>11$ & 93 & 30.0 & Livestock & 105 & 33.9 \\
\hline Distance to farm & & & Total & 310 & 100 \\
\hline$<10$ & 83 & 26.8 & & & \\
\hline \multicolumn{5}{|l|}{ Source: field survey data; 2018.} &
\end{tabular}

The farm sizes were majorly less than 2 hectares with a good proportion $59.0 \%$ cultivating between 1.0 to 2.0 hectares and $23.2 \%$ cultivating less than 1.0 hectare. This depicts that majority of the farmers operate at small scale level. Furthermore, the results shows that majority $58.7 \%$ of the farmers had a family size within the range $6-11$ people while $30.0 \%$ had above 11 people. This findings specifies that majority of the farmers had large house hold sizes which suggest availability of labour. This result is in consonance with the report of Sani; Danwanka \& Ma'ule (2015) which stated that increase in family size leads to increase in demand of labour. Majority of the farmers were located farther away from their farms, about $42.3 \%$ of the farmers had $11-30 \mathrm{~km}$ while $26.8 \%$ had less than $10 \mathrm{~km}$, more so $18.4 \%$ and $12.6 \%$ of the farmers had farm distances of $31-50 \mathrm{~m}$ and above $50 \mathrm{~km}$ respectively.

Based on age, majority of the farmers $66.2 \%$ falls within $31-50 y e a r s$ implying that majority of the respondents are within their youthful and active age signifying the zeal and wiliness to cope and manage the impact of insecurities. More so, $60.3 \%$ of the

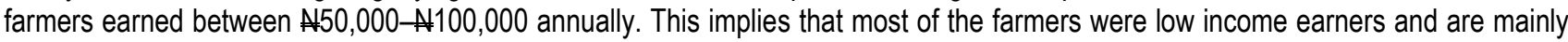
small scale farmers denoting that production activities would be in a low level. Furthermore, $66.1 \%$ of the respondents were crop farmers while $33.9 \%$ of the respondents were livestock farmers; majorly, pastoralist which are mostly nomadic in their operations, on the number of times visited by an extension officer, $59.0 \%$ of the farmers were visited $5-10$ times, while $31.6 \%$ and $9.4 \%$ of the respondents were visited less than 5 times and above 10 times respectively. Extension visit are aimed at introducing to the farmers new methods and technologies to be adopted in mitigating insecurities and other production practices.

\section{Farmers Perception and Management of Insecurities}

Table-2 revealed that farmers in Bauchi State, Nigeria had perceived and experienced various insecurities. With a mean score at 3.0, the fourteen security challenges were all significant as ranked. The most highly perceived insecurity was Herders/Farmers clashes and the least perceived was occurrence of soil erosion. Between these two security challenges, they also perceived in descending order the following insecurities: drought, fire outbreak, diseases, inadequate technologies, ill health, policy inconsistency, flood, pricing/hedge-outs, kidnappings, pests, cultural/social taboos, theft/roastling and soil erosion.

In response to these insecurities, they applied some cultural and operational mitigation measures to manage the insecurities that include formation of local vigilante, farm irrigation, slashing the bush ends of farmlands to act as fire break against fire outbreaks, keeping surveillance over farms and harvesting crops promptly to guard against thieves. Other measures are setting of traps for mammalian rodents, pests and birds and planting resistant varieties of crops as well as rearing disease resistant breeds of livestock. The use of shifting cultivation was rampant as a hedge over drought, theft, soil erosion while nomadic rearing pattern was practiced as a means of getting fresh soilage as against silage usage which is common in ranches with its attendant effects which include herders/farmers clashes, constructing contiguous earth mounds to block water inflows, planting cover crops and constructing water channels that ended in distant ditches to also control soil erosion and flood. 
Table-2: Farmers' level of perception and management of insecurities

\begin{tabular}{|c|c|c|c|c|c|c|c|c|}
\hline \multirow[t]{2}{*}{ Insecurity } & \multicolumn{5}{|c|}{ Farmers Insecurity Perception } & \multirow[b]{2}{*}{ Total Score } & \multirow[b]{2}{*}{ Mean } & \multirow[b]{2}{*}{ Rank } \\
\hline & $\begin{array}{l}\text { Strongly } \\
\text { Agree }\end{array}$ & Agree & Undecided & Disagree & $\begin{array}{l}\text { Strongly } \\
\text { Disagree }\end{array}$ & & & \\
\hline \multirow[t]{2}{*}{ Cultural taboos } & 103 & 98 & 16 & 52 & 41 & 1,100 & 3.55 & $12^{\text {th }}$ \\
\hline & $(515)$ & $(392)$ & $(48)$ & $(104)$ & (41) & & & \\
\hline \multirow[t]{2}{*}{ Theft Roastling } & 85 & 112 & 10 & 61 & 42 & 1,067 & 3.44 & $13^{\text {th }}$ \\
\hline & $(425)$ & $(448)$ & (30) & $(122)$ & (42) & & & \\
\hline \multirow[t]{2}{*}{ Policy inconsistency } & 124 & 101 & 5 & 42 & 38 & 1,161 & 3.75 & $7^{\text {th }}$ \\
\hline & $(620)$ & (404) & (15) & (84) & (38) & & & \\
\hline \multirow[t]{2}{*}{ Flood } & 99 & 110 & 22 & 71 & 8 & 1,151 & 3.71 & $8^{\text {th }}$ \\
\hline & (495) & $(440)$ & (66) & $(142)$ & (8) & & & \\
\hline \multirow[t]{2}{*}{ Diseases } & 137 & 97 & 6 & 37 & 33 & 1,198 & 3.86 & $4^{\text {th }}$ \\
\hline & (685) & (388) & (18) & (74) & (33) & & & \\
\hline \multirow[t]{2}{*}{ Pests } & 83 & 134 & 15 & 43 & 35 & 1,117 & 3.60 & $11^{\text {th }}$ \\
\hline & (415) & $(536)$ & (45) & (86) & (35) & & & \\
\hline \multirow[t]{2}{*}{ Draught } & 141 & 88 & 12 & 47 & 22 & 1,209 & 3.90 & $2^{\text {nd }}$ \\
\hline & $(705)$ & $(352)$ & (36) & (94) & (22) & & & \\
\hline \multirow[t]{2}{*}{ Soil Erosion } & 72 & 112 & 25 & 61 & 40 & 1,045 & 3.37 & $14^{\text {th }}$ \\
\hline & $(360)$ & $(448)$ & $(75)$ & $(122)$ & $(40)$ & & & \\
\hline \multirow[t]{2}{*}{ Kidnapping } & 87 & 125 & 31 & 24 & 43 & 1,119 & 3.61 & $10^{\text {th }}$ \\
\hline & (435) & $(500)$ & (93) & (48) & (43) & & & \\
\hline \multirow[t]{2}{*}{ III Health } & 124 & 107 & 4 & 31 & 44 & 1,166 & 3.76 & $6^{\text {th }}$ \\
\hline & $(620)$ & $(428)$ & (12) & (62) & (44) & & & \\
\hline \multirow[t]{2}{*}{ Fire Outbreak } & 107 & 123 & 25 & 47 & 8 & 1,204 & 3.88 & $3^{\text {rd }}$ \\
\hline & (535) & (492) & (75) & (94) & (8) & & & \\
\hline \multirow[t]{2}{*}{ Farmer Clashes } & 137 & 112 & 11 & 32 & 18 & 1,248 & 4.03 & 1 st \\
\hline & $(685)$ & $(448)$ & (33) & $(64)$ & $(18)$ & & & \\
\hline \multirow[t]{2}{*}{ Pricing/Hedge-outs } & 103 & 101 & 20 & 57 & 29 & 1,122 & 3.62 & $9^{\text {th }}$ \\
\hline & $(515)$ & (404) & $(60)$ & $(114)$ & (29) & & & \\
\hline \multirow{2}{*}{$\begin{array}{l}\text { Inadequate } \\
\text { Technology }\end{array}$} & 129 & 103 & 25 & 12 & 41 & 1,197 & 3.86 & $5^{\text {th }}$ \\
\hline & (645) & $(412)$ & (75) & (24) & (41) & & & \\
\hline Total & 1,531 & 1,523 & 227 & 617 & 442 & & & \\
\hline
\end{tabular}

\section{Determinants of Choice of Management Strategy against Insecurity by Farmers}

Farmer's choice of insecurity management strategy was hypothesized to be influenced by their socio-economic attributes. The result of the binary probit model analysis presented in Table-3 showed that the explanatory power of the specified variables as indicated by the pseudo $\mathrm{R}^{2}$ value of $(0.783)$ was relatively good. This indicates that the estimated independent variables are responsible for about $78 \%$ variation in farmers' management decision on insecurities. The overall goodness of fit as reflected by prob. $>\operatorname{chi}^{2}(0.000)$ was also good. In terms of consistency with a priori expectations on the relationship between the dependent variable and the explanatory variables; the model seems to have behaved well. Out of the ten explanatory variables specified in the mode, seven were statistically significant. 
Table-3: Parameter estimates and marginal effects of the probit model analysis of socio-economic determinants of farmer's choice of insecurity management strategies

\begin{tabular}{|c|c|c|c|c|}
\hline \multirow[t]{2}{*}{ Variables } & \multicolumn{2}{|c|}{ Parameter Estimate } & \multicolumn{2}{|c|}{ Marginal Effects } \\
\hline & Coefficients (b) & Std. Error & Change in Prob. & Std. Error \\
\hline \multirow[t]{2}{*}{ Sex } & 0.04357 & 0.0250 & 0.02740 & 0.0035 \\
\hline & $(0.134)$ & & $(0.134)$ & \\
\hline \multirow[t]{2}{*}{ Education } & 0.32163 & 0.5037 & 0.08720 & 0.0317 \\
\hline & $(3.247) \mathrm{xxx}$ & & $(3.247) x x x$ & \\
\hline \multirow[t]{2}{*}{ Farm Experience } & 0.7348 & 0.0071 & 0.03741 & 0.0009 \\
\hline & $(2.374) x x x$ & & $(2.374) x x x$ & \\
\hline \multirow[t]{2}{*}{ Farm Size } & -0.6927 & 0.4381 & 0.07146 & 0.0439 \\
\hline & $(2.137)^{x x}$ & & $(2.137)^{x x}$ & \\
\hline \multirow[t]{2}{*}{ Enterprise Type } & 1.2031 & 0.0530 & 0.00394 & 0.0039 \\
\hline & $(1.037)$ & & $(1.037)$ & \\
\hline \multirow[t]{2}{*}{$\mathrm{HH}$ Size } & 4.2730 & 0.0172 & 0.09217 & 0.0025 \\
\hline & $(2.437) x x$ & & $(2.437) x x$ & \\
\hline \multirow[t]{2}{*}{ Distance } & -0.7256 & 0.4113 & 0.09725 & 0.0731 \\
\hline & $(3.126) x x x$ & & $(3.126) x x x$ & \\
\hline \multirow[t]{2}{*}{$\mathrm{HH}$ Income } & 1.8374 & 0.452 & 0.02614 & 0.0692 \\
\hline & $(1.847)^{x}$ & & $(1.847)^{x}$ & \\
\hline \multirow[t]{2}{*}{ Extension Visit } & 0.1482 & 0.0381 & 0.04137 & 0.0032 \\
\hline & $(0.831)$ & & $(0.831)$ & \\
\hline \multirow[t]{2}{*}{ Perception Level } & 0.8359 & 0.3493 & 0.02972 & 0.0439 \\
\hline & $(2.314) x x$ & & $(2.314)^{x x}$ & \\
\hline \multirow[t]{2}{*}{ Constant } & -3.2438 & 0.5938 & & \\
\hline & $(3.489) x x x$ & & & \\
\hline
\end{tabular}

$x, x x$, and $x x x$ significant levels at $10 \%, 5 \%$ and $1 \%$ alpha level of probability. Figures in parenthesis ( ) are T-ratios; LR Chi² = 42.37; Pseudo R² $=0.783 ;$ Prob. $>\mathrm{Chi}^{2}=0.000$

Number of observation $=310$. For the marginal effects, $\left({ }^{x}\right) d y / d x$ is for discrete change of dummy variable from 0 to $1 ; z$ and $p>/ z /$ correspond to the test of the underlying coefficient being 0 .

The parameter estimates of the probit model only provided the direction of the influence of the explanatory variables on farmers' management strategy for insecurity and did not show the actual magnitude of change or probabilities in the coefficients. Thus, the marginal effects $(\mathrm{dy} / \mathrm{dx})$ from the probit model, which measures the expected change in probability of choice of management strategy for insecurity with respect to a unit change in an independent variable was also presented in Table-3.

Education of the farmers was significant $(P<0.01)$ and positively related with the choice of management strategy for insecurity. This entails that educated farmers are more likely to adopt various management strategies to counter insecurities than the uneducated counterparts. The result of the marginal effect on farmers education suggests than an additional one unit increase in years of education of the farmers would result in $0.08720(8.7 \%)$ increase in the probability of reacting more positively through management strategies to insecurity. This seems to agree with the report of World Bank [8] which showed that there is positive relationship between education and risk management. Acquired formal education or knowledge is cherished motivators that jealously guide an entrepreneur to invest in measures to protect self against inherent losses.

Farmers years of farming experience was also positive and significantly influenced choice of management strategies for insecurity at $\mathrm{P}<0.01$. In other words, experience farmers are more likely to be more aggressive in adopting measures to combat security challenges. The result of the marginal effect on farmers experience implies that an additional one unit increase in years of farming experience of the farmers would in 0.03741 (3.7\%) increase in probability of using various managements strategies in tackling insecurities in the farm enterprises. Ogundele and Okoruwa [16] stated that to be competent enough to handle all the vagaries of agriculture, farmers need experience through the years he has stayed in the farm to increase farm output. Insecurities which posses major threats to output are paramount in this regards.

The coefficient of farm size was significant $(P<0.05)$ but negatively related with the choice of management strategy for insecurity. The indication of the negative relationship was that, as farmers' farm size increases, the likelihood of adopting management strategies for security challenges reduces. This may not be unconnected with the scattered nature of the fragmented, small scale farm holdings. The result of the marginal effect on farm size suggests that an additional one unit increase in farm size would result in $0.07146(7.1 \%)$ decrease in the probability of using management strategies for farm insecurities. This observation truly attests to small 
scale farming intensity of use of cultural measures in providing adequate protection to unforeseeable losses. This result conforms to report by Salimonu and Falusi [4].

Household size was positive and significant $(P<0.05)$ with farmers' choice of management strategy for insecurity. The effect of household size implies that farmers with large number of people in their households are more likely to manage insecurities than those with small household size. The result of the marginal effect on household size reveals that an additional one unit increase in household size would result in $0.09217(9.2 \%)$ increase in the likelihood of managing insecurities in the farm. Ballayan [17] was of the opinion that management of security challenges are not only cost intensive but labour intensive in terms of management, mitigation and control.

Distance to the farm was significant $(P<0.01)$ and negatively related with management strategy of insecurity. This implies that, the longer the distance, the lower the likelihood of adopting management strategies for insecurity vice versa. The result of the marginal effect on distance suggests that an additional one unit increase in distance would result in $0.09725(9.7 \%)$ decrease in probability of managing security challenges in the farm. The result was in consonance with a priori expectation and work by Arene [18] who reported that distance had a negative relationship with agricultural productivity. This is because; distance tends to discourage farmers from putting their best.

Household income was significant $(P<0.010)$ and positively related with the choice of management strategy for insecurity. This implies that a household with higher income will adopt management strategies for insecurity than the lower income counterparts. The result of the marginal effect on household income suggests that an additional one unit increase in household income would result in $0.02614(2.6 \%)$ increase in probability of managing farms' security challenges. Sivakumer, Mortha and Das [7] reported that natural disaster can be mitigated at the farm level by the farmers when there are available financial resources to address the impact.

Farmers' perception level was also positive and significantly influenced management strategy for insecurity at $(P<0.05)$. In other word, farmers who have awareness of farm enterprise security challenges are more likely to be willing to adopt management strategies to mitigate their impact. The result of the marginal effect on farmers perception level implies that an additional one unit increase in level of perception of the farmers would result in $0.02972(2.9 \%)$ increase in probability of managing the security challenge. This result conform with the findings by Junge, Deji, Abaidoo, Chikoye and Stahr [19] who reported a positive and significant relationship between awareness and adoption of new technologies in soil conservation practices.

\section{Conclusions And ReCOMmENDATIONS}

The paper estimated the perception and determinants of management strategy for insecurity of farm enterprise in Bauchi State, Nigeria. In carrying out the study, effort was made to investigate various security challenges faced by farmers and the management strategies adopted to mitigate the impacts of such challenges. All the fourteen security challenges investigated in the study were statistically significant as perceived security threats by the respondents, meaning that farmers in the study area have perceived and experienced all the security challenges, the most which is herders/farmers clashes and the least perceived was soil erosion.

The socio-economic attributes of the farmers that significantly influenced the choice of management strategy to be adopted in the mitigation of the farm insecurities include: education, farming experience, farm size, household size, distance, household income and insecurity perception level of the farmers. Based on the findings of this study, the following recommendations were suggested.

- Credit facilities should be made available to the farmers in form of soft loans to enable them procure technologies and necessary inputs to cope with insecurities.

- Provision of required infrastructural facilities, education and institutional supports to the farmers should be made a priority by government.

- Farmers should be encouraged by farm extension agency to take up formal insurance policy from designate companies against losses of their enterprises.

- Formation of local vigilante/policing structure should be encouraged to tackle headlong insecurity issues.

- Government should address issues of policy inconsistency and bureaucracy by building viable institutions.

- Pastoralists should be encouraged to practice modern livestock management practice of ranching and should be dissuaded from the ancient archaic nomadic method.

\section{REFERENCES}

1. National Bureau of Statistics (NBS). (2018). Rural Demographic Survey Report. Abuja. Nigeria. 5-10.

2. Agenor, P. R., Izquierdo, A., \& Fofack, H. (2004). IMMPA: A Quantitative Macroeconomic Framework for the Analysis of Poverty Reduction Strategies. The World Bank, Washington D.C.

3. Park, I. (2014). Security Challenges, Agricultural Production and Food Security in Nigeria. Proceedings of the $28^{\text {th }}$ Annual Conference of Farm Management Association of Nigeria (FAMAN); 9-20. 
4. Salimonu, K. K., \& Falusi, A. O. (2009). Sources of Risks and Management Strategies among Food Crop Farmers in Osun State, Nigeria. African Journal of Food, Agriculture, Nutrition and Development, 9(7): 1591-1605.

5. Cherry, K. (2010). Perception and the Perceptual Process; the Everything about Psychology Book. An Introduction Guide to Science of Human Behaviour. (2nd ed). Adam Media, U.S.A, 287.

6. Carter, M. R., \& Barrett, C. B. (2006). The Economics of Poverty Trap and Persistent Poverty: An Asset Based Approach. Journal of Development Studies, 42(2):178-199.

7. Sivakumer, M. V. K., Motha, R. P., \& Das, H. P. (2005). Natural Disasters and Extreme Events in Agriculture: Impact and Mitigation. Science and Business Springer, 367.

8. World Bank. (2005). Managing Agricultural Production Risks: Innovation in Developing Countries. Report No.32727-GLB.

9. Botkin, D. B., \& Keller, E. A. (1997). Environmental Science: Earth as a living planet. Second Edition, John Wiley and Sons, New York. 626.

10. Wikipedia (2018). Bauchi State Government: The free encyclopedia. Retrieved from http://www.wikipedia.org/wiki/Bauchistate. 20th Nov, 2018.

11. BSADPP. (2018). Situation Report. Technical Report of Bauchi State Agricultural Development Programme, 1-15.

12. Tobin, J. (1958). Estimation of Relationships for Limited Dependent Variables. Econometrica. 26:24-36.

13. Amamiya, T. (1981). Qualitative Response Models: A Survey. Journal of Eco. Lit. 19:1483-1536.

14. Heckman, I. J. (1976). The Common Structure of Statistical Models of Truncation, Sample Selection and Limited Dependent Variables and a Simple Estimation for such Models. Ann. Eco. Soc. Measure. 5:475-492.

15. CIAS. (2002). Women on Farms, Juggling Roles and Responsibilities. Centre for Integrated Agricultural System (CIAS).

16. Ogundele, O. O., \& Okoruwa, V. O. (2006). Technical Efficiency Differentials in Rice Production Technologies in Nigeria. (AERC Research Paper 154). Nairobi, Kenya. African Economic Research Consortium.

17. Ballayan, D. (2000). Soil Degradation: Rome; Food and Agricultural Organization (FAO).

18. Arene, C. J. (1992) Loan Repayment and Technical Assistance among Small-holder Maize Farmers in Nigeria. Africa Review of Money, Finance and Banking, 63-74.

19. Junge, B., Deji O., Abaidoo, R., Chikoye, C., \& Starhr, K. (2009). Farmers' Adoption of Soil Conservation Technologies: A case study from Osun State, Nigeria. Journal of Agricultural Education and Extension, 15(3):257-274. 